OBJECT LESSONS 
NEXT WAVE: NEW DIRECTIONS IN WOMEN'S STUDIES

A series edited by Inderpal Grewal, Caren Kaplan, and Robyn Wiegman 


\section{OBJECT LESSONS}

Robyn Wiegman

DUKE UNIVERSITY PRESS DURHAM \& LONDON 2012 
(C) 2012 Duke University Press

All rights reserved

Printed in the United States of

America on acid-free paper $\infty$

Designed by Amy Ruth Buchanan

Typeset in Garamond Premier Pro

by Westchester Book Group

Library of Congress Cataloging-in-

Publication Data appear on the

last printed page of this book. 